\title{
НОВАЦІЙНІ МЕТОДИКИ ПСИХОФІЗИЧНОГО ТРЕНІНГУ Є. ГРОТОВСЬКОГО
}

\begin{abstract}
Мета статті - проаналізувати новаиійні методики психофізичного тренінгу Є. Гротовського в контексті формування новітньої системи навчання актора; визначити актуальність інтеграції психологічного та фізичного аспектів у проиесі створення та відтворення художнього образу. Методологія дослідження базується на приниипах об'єктивності, історизму, багатофакторності, системності, комплексності, розвитку та плюралізму, а для досягнення мети використані методи наукового пізнання: проблемно-хронологічний, конкретно-історичний, статистичний, описовий, логіко-аналітичний. Наукова новизна. Проведено мистеитвознавчий аналіз сучасних методик психофізичного тренінгу С. Гротовського; розглянуто унікальні принципи навчання актора - втілення усіх можливих виражальних засобів театрального мистеитва (за С. Гротовським), котрі базуються на досвіді театральних режисерів різних країн; визначено важливість інтегрованого психологічного та фізичного навчання в контексті створення та відтворення художнього образу. Висновки. Методика Є. Гротовського сприяє віднайденню актором глибокого розуміння себе та своєї професії за допомогою психофізичного дослідження того, як вийти за межі звичок та блоків. На сучасному етапі театральними режисерами та акторами - інструкторами методик за психофізичним тренінгом С. Гротовського, досліджено розумові та фізичні перешкоди, які найчастіше проявляються в акторів на сцені, а також розглянуто роль уяви в навчанні акторів на основі рухів. Специфіка новаційних методик навчання акторів полягає не в копіюванні конщепцій та вправ тренінгу С. Гротовського, а в своєрідній адаптації та розвитку набутих навичок у поєднанні з власними підходами. Проаналізовані нами методики засвідчують здатність актора розвинути власні не лише фізичні, а й духовні здібності, проте не иляхом оволодіння професійними навичками, а шляхом досягнення абсолютної иілісності фізіологічних та інтелектуальних здібностей, а відтак актуалізують питання формування термінологічної бази та системи критеріїв новітніх підходів до сиенічної акторської майстерності.
\end{abstract}

Ключові слова: С. Гротовський, психофізичний тренінг, методики, актор, художній образ, сиенічний простір.

Цель статьи - проанализировать инновационные методики психофизического тренинга Е. Гротовского в контексте формирования новой системь обучения актера; определить актуальность интеграции психологического и физического аспектов в процессе создания и воспроизведения художественного образа. Методология исследования базируется на принципах объективности, историзма, многофакторности, системности, комплексности, развития и плюрализма, а для достижения иели-использованы методы научного познания: проблемно-хронологический, конкретно-исторический, статистический, описательньй, логико-аналитический. Научная новизна. Проведен искусствоведческий анализ современных методик психофизического тренинга Е. Гротовского; рассмотрены уникальные принципы обучения актеравоплощение всех возможных выразительных средств театрального искусства (по Е. Гротовскому), основанные на опыте театральных режиссеров разных стран; определена важность интегрированного психологического и физического обучения в контексте создания и воспроизведения художественного образа. Выводы. Методика Е. Гротовского способствует нахождению актером глубокого понимания себя и своей профессии с помощью психофизического исследования того, как выйти за пределы привычек и блоков. На современном этапе театральными режисерами и актерами - инструкторами методик по психофизическим тренингам Е. Гротовского, исследованы умственные и физические препятствия, которые чаще всего проявляются у актеров на сиене, а также рассмотрена роль воображения в обуче- 
нии актеров на основе движений. Специфика новационных методик обучения актеров заключается не в копировании конщепщий и упражнений тренинга Е. Гротовского, а в своеобразной адаптаџии и развитии приобретенных навыков в сочетании с собственными подходами. Проанализированные нами методики свидетельствуют о способности актера развить собственные не только физические, но и духовные способности, однако не путем овладения профессиональными навыками, а путем достижения абсолютной целостности физиологических и интеллектуальных способностей, а потому актуализируют вопросы формирования терминологической базы и системы критериев новых подходов к сиенической актерской мастерства.

Ключевые слова: Е. Гротовский, психофизический тренинг, методики, актер, художественный образ, сиеническое пространство.

The purpose of the article is to analyze the innovative methods of the psycho-physical training of E. Grotowskyi in the context of the formation of the newest actor education system; to determine the urgency of the integration of the psychological and physical aspects in the process of creation and reproduction of the artistic image. The methodology of the research is based on the principles of objectivity, historicism, multifactority, systemicity, complexity, development and pluralism, and to achieve the goal, the methods of scientific knowledge are used: problem-chronological, concrete historical, statistical, descriptive, logical-analytical. Scientific novelty. An art critic analysis of modern methods of psychophysical training by E. Grotowskyi was conducted; The unique principles of teaching the actor - the embodiment of all possible expressive means of theatrical art (according to E. Grotovsky) - are based on the experience of theatrical directors from different countries; the importance of integrated psychological and physical training in the context of creation and reproduction of artistic image is determined. Conclusions. Y. Grotowskyi's method contributes to gaining a deep understanding of himself and his profession by the actor through psychophysical studies of how to go beyond habits and blocks. At the present stage, theatrical directors and actors instructors of techniques for psychophysical training by E. Grotowskyi have investigated the mental and physical obstacles that are most often manifested in actors on the stage, as well as the role of imagination in learning actors based on motions. The specificity of innovative methods of teaching actors is not to copy the concepts and exercises of E. Grotowskyi's training, but to adapt and develop their acquired skills in combination with their own approaches. The methods analyzed by us testify to the ability of the actor to develop not only their own physical but also spiritual abilities, but not through the acquisition of professional skills, but through the achievement of the absolute integrity of physiological and intellectual abilities, and thus actualizing the question of the formation of the terminological basis and the criteria criteria of the newest approaches to the stage actor skill.

Key words: J. Grotovskyi, psychophysical training, methods, actor, artistic image, scenic space.

Специфіка театрального мистецтва на сучасному етапі характеризується новаційним баченням режисерів, різноманітними інтерпретаціями, переосмисленням та контекстуалізацією традиційних сценічних творів, таких як давньогрецька трагедія та комедія, п’єси класичної зарубіжної та вітчизняної драматургії. Подібна тенденція спостерігається і щодо різноманітних відомих психофізичних методів навчання акторів, котрі еволюціонують та дистилюються, отримують подальше уточнення та практичне застосування.

Проведення аналізу особливостей методик за психофізичними тренінгами Є. Гротовського на сучасному етапі має важливе значення для осмислення проблематики світового театрального мистецтва та новітньої системи навчання актора. Оскільки акторська підготовка - еволюціонуюче природне мистецтво, вважаємо за доцільне дослідити та проаналізувати в історичній ретроспективі розвиток психофізичного тренінгу С. Гротовського, від оригінального варіанта до новітніх інтерпретацій.

Мета дослідження - проаналізувати новаційні методики психофізичного тренінгу Є. Гротовського в контексті формування новітньої системи навчання актора; визначити актуальність інтеграції психологічного та фізичного аспектів в процесі створення та відтворення художнього образу.

Аналіз публікацій засвідчує: незважаючи на велику кількість наукових досліджень, присвячених особливостям театральної діяльності та акторського тренінгу Є. Гротовського, здійснених вітчизняними (Н. Шевченко «Психофізичний акторський тренінг як енергетичний процес», 2005 р.; Т. Фруктова «Антропологічний поворот ігрової концепції театру Єжи Гротовського: естетика нової чуттєвості», 2009 р. та ін.) науковцями, в яких аналізуються основні 
положення ідеологічної концепції «вбогого театру» в процесі акторського самопізнання, а також зарубіжними дослідниками (Ш. Лендра «Бейлі та Гротовський: деякі паралелі в навчальному процесі», 1991 р.; Л. Волфорд «Дослідження об’єктивної драми Гротовського», 1996 р. та ін.), інноваційні методики за психофізичним тренінгом $€$. Гротовського не стали предметом грунтовного наукового дослідження.

Виклад основного матеріалу. Фізичні прояви людського стану стоять у центрі виконавської майстерності. Наприклад, мім у стародавніх греків, як форма, що пов'язана з фізичною розповіддю історії; давні азіатські вистави, в тому числі японські Кабукі та Но, Китайська опера та Санскритський театр, в яких кодифіковані жести та символічні рухи репрезентовані в єдиному складному дійстві (прогулянка малим колом означає тривалу подорож в традиційному китайському театрі; розмахування руками і всіма пальцями в Санскритському театрі означає дощ та ін.); стародавні африканські форми виконавської майстерності, в яких різниця між танцями і театром зовсім незначна або її взагалі немає - усі рухи $є$ частиною виразності виконавства. В середині XVI ст. італійські виконавці Комедіа дель арте покладалися на фізізацію як на один із засобів спілкування на сцені та розважання глядачів - спритні жартівливі фізичні дії, вставні буфонадні трюки з арсеналу комічних персонажів або, насамперед, невеличкі імпровізаційні сценки, так звані лацці (lazzi) (Smith, 1912, pp. 5-10).

Рухи в постановках можуть передавати відомості про соціальний статус, культурні, гендерні та моральні характеристики героїв, їх особистісне ставлення до інших персонажів або подій та ін. Засоби фізичної виразності надають на сцені стільки ж інформації про персонаж та події, як і мовні. У XIX ст. французький теоретик сценічного мистецтва $\Phi$. Дельсарт кодифікував власну систему виражальних засобів, поєднавши жести, рухи тіла та мову. К. Станіславський, який на думку багатьох дослідників є засновником психологічного реалізму в дії, наголошував на важливості балансу між внутрішньою, ментальною розміреністю та внутрішньою фізичною дією, особливо в більш пізніх працях. Терміни «внутрішній» та «зовнішній» слугують введенням до теорії К. Станіславського про майстерність актора, розробку персонажа та розвиток дії, а їх баланс - необхідною умовою для створення повноцінного образу (Toporkov, 1998, p. 34).

Внесок $Є$. Гротовського в розвиток театрального мистецтва варіюється від створення сценічних постановок, теорії та критики до навчання акторів.
Багатогранна спадщина польського режисера на сучасному етапі сприяє проведенню різнопланових мистецтвознавчих та культурологічних наукових досліджень і розробок у галузі навчання акторської майстерності, оскільки запропонована ним методика лишається однією з найбільш доступних для сучасних акторів-практиків та студентів театральних закладів у багатьох країнах світу.

Д. Слов'як $(2007$, р. 3$)$ зазначає, що на формування методики С. Гротовського неабиякий вплив справила книжка П. Брантона «Мандрівка в таємничу Індію» (1934р.), кілька розділів якої присвячено Шрі Рамане Махарші - відомому індійському філософові, який створив власне вчення на основі адвайта-веданти, де самопізнання зосереджується на понятті «Я» і на питаннях до себе самого: «Хто я?», «Що таке я?» та ін. (Zimmer, 1948, p. 23), решта ж-взаємодії мандруючого Індією англійця 3 мудрецями, гуру, йогами, які шукають містичну мудрість і стан присутності. Є. Гротовський розпочинає власний пошук, проводячи дослідження роботи в театрі, акторської виразності тощо. Внаслідок інтерпретації системи фізичних дій К. Станіславського, котра передбачає вихід за межі емоційної та психологічної пам'яті як основи дії і віднайдення взаємозв'язку між фізичною дією та психологічною відповіддю, та продовжуючи дослідження його методу фізичної дії, Є. Гротовський, акцентуючи на тому, що осмислене зростання не відбувається випадково або самостійно (Richards, 1995, p. 105), створив власну методику, яка сприяе глибокому, осмисленому розумінню актором себе самого та професії.

У 1959 р. С. Гротовський заснував «Театр 13 рядів» (з 1962 р.— «Театр-Лабораторія») в південній частині польського міста Ополе, головним аспектом діяльності якого було визначення характерного для театру, а персональна техніка актора розглядалася як ядро театрального мистецтва. У пошуках засобів позбавлення спротиву акторського організму, була створена методика, результатом якої стала свобода від тимчасового інтервалу між внутрішнім імпульсом та зовнішньою реакцією таким чином, що імпульс стає вже зовнішньою реакцією, тобто імпульс виникає одночасно з дією і «глядач бачить не тіло, а ряд видимих імпульсів» (Grotowski, 1995, pp. 15-16).

Деякі сучасні дослідники поділяють діяльність Є. Гротовського на п’ять етапів: «Театр продюсування», або «Бідний театр» (1959-1969); «Паратеатр» (1969-1978); «Театр джерел» (1976-1982); «Об'єктивна драма» (1983-1992); та «Мистецтво як транспортний засіб» (1991-1999р.), для яких основоположними $є$ завдання віднайдення правди- 
вості на сцені, усунення затисків та встановлення психофізичного зв'язку. Проте, на думку польського науковця 3. Осінського (1980, р. 25), формування театральної концепції та режисерського методу Є. Гротовського відбувалися протягом 1959-1969 pp., тоді як упродовж 1970-1990-х рр. театральні принципи режисера набували розвитку в процесі нових експериментів. Дослідник виділяє у цьому процесі три етапи: 1959-1961 pp.- - рух від використання принципів К. Станіславського до автономного театру, як мистецтва незалежного від дійсності, підкореного власним театральним законам, в якому актор - як частина філософського видовища - постає автором емоційного наповнення вистави (акцент у методиці робиться на зовнішній виразності акторського апарату - ідеальна акторська техніка поєднується з емоціями) - робота актора допомагає впливати на глядацьку реакцію; 1962-1964рр. («На шляху до убогого театру») - дослідження питання ритуалу в театрі, осмислення сценічної діяльності акторів як втілення архетипів, котрі відкривають вроджені структури несвідомого, своєрідний осад життєвих ситуацій, завдань та вчинків людини, які постійно повторюються (сприйняття людського тіла як елемента ритуалу; пошук лаконічних та яскравих знаків людських почуттів; фізично вивірені чіткі рухи та гра зі сценічним простором як основа побудови ролі). Акторський тренінг на цьому етапі спрямований на знаходження знаків та вироблення стереотипів задля створення зв'язку зі світом глядачів, а віртуозність акторської техніки (ідеальне володіння тілом без наповнення образу емоціями або психологією), котра виробляється через жести та інтонацію і покликана створювати в психіці глядачів певні асоціації, дає змогу знайти найточніші засоби виразності; 1965-1969 рр.- -етап формування основних принципів концепції убогого театру та методики підготовки актора, що базується на поєднанні принципів східної філософії та практики буддизму з ідеями А. Арто про верховенство звукової партитури ролі та дихання, а також новітні психологічні підходи до ролі при проведенні тренінгів (пошук актором рис ідеальної категорії, яка зображується ним на сцені у власній фізіології та психології; позбуття актором комплексів, страхів, пристосувань, як елементів повсякденної психології та створення абстрактного надособистісного шару, що спрямований до несвідомого, задля створення образів-архетипів, які зрозумілі глядачу попри вікові, гендерні та інші особливості).

Аналіз етапів формування психофізичного тренінгу Є. Гротовського засвідчує еволюційність даного підходу впродовж певного часу — від тради- ційних навчальних занять для акторів, дослідження ритуальних, культурних традицій та людського стану з неперспективної точки зору до остаточного етапу переглянутого навчання акторів, з новим розумінням, ставленням та зв' язками за межами традиційної західної практики виконавської майстерності.

Розблокування та вивчення психофізичного процесу залишалося важливою частиною кожного етапу Є. Гротовського, попри те, що фокусування та методика вивчення відрізнялися. Відтак методику режисера можемо вважати еволюційною від початку, оскільки, базуючись на досвіді йоги, азіатських вистав, гаїтянському народному танці й музиці, а також на праці К. Станіславського про фізичні дії, вона набувала нових форм у розвитку.

Театр досліджує стани людини - несталу субстанцію, яка перебуває у постійному розвитку. Відтак підходи, методики та тренінги, які за своєю концепцією взаємодіють $з$ цією данністю, побудовані за принципом «досконалість суперечить роботі» — так само як і їх учасники, інструктори лишаються відкритими для результатів самопізнання, щоб зберігати актуальність методики на сучасному етапі та посприяти створенню учасниками власних версій навчання.

Таким чином, методика Є. Гротовського, окрім розширення діапазону виражальних засобів шляхом регулярних фізичних, розумових та мовних самовдосконалень, має на меті відкриття особистого способу створення сценічного образу та винайдення власного художнього підходу.

Є. Гротовський продовжував експериментувати та розробляти власний підхід протягом життя, а кожен із його учнів, залучений до цього дослідження, розглядав навчання як лабораторію - замість пошуку конкретних відповідей, ідеться про збір інформації - i наразі передає цю точку зору своїм учням.

М. Коморовська - відома польська актриса і педагог, яка співпрацювала з С. Гротовським упродовж 1961-1968 рр., акцентує на важливості сприйняття особливого способу мислення режисера, концентрації на тому, що надає мистецтву театру своєрідності - на взаємовідносинах глядача i актора, здатності актора зазнавати трансформацій безпосередньо перед глядачем та на архітектурі сценічного простору як місці їх зустрічі (Komorowska, 2015 , p. 57). Новаційним підходом М. Коморовської до психофізичного тренінгу Є. Гротовського $\epsilon$ акцентування на розблокуванні пам'яті тіла та концентрації, оскільки тіло актора має бути чуттєвим інструментом, без якого сценічна творчість неможлива, а також співіснуванні спонтанності та 
дисципліни, котрі не є взаємовиключними, а радше протилежними поняттями, що «не послаблюють одне одного, а взаємопосилюють» (Grotowski, 1995, p. 89). Посилаючись на думку С. Гротовського, що повсякденна природність сприяє приховуванню істини, а «форма схожа на пастку 3 наживкою на яку духовний процес реагує спонтанно і проти якої він бореться» (Grotowski, 1995, p. 17), М. Коморовська (2015, p. 58) акцентує на важливості процесу перетину власних кордонів та обмежень під час побудови форм, імпульсів і наборі знаків.

Дана методика навчання не передбачає опанування доскональної техніки, оскільки стиль навчання не передбачає завершення, а є невичерпним. Незважаючи на те, що багато вправ із тренінгів дають акторові можливість досліджувати фізичність, а за умови регулярної практики впродовж тривалого часу сприяють накопиченню сили, вона не позиціонувалася як фізична практика для отримання певних фізичних навичок, оскільки фізичні форми, які є основою методики, позиціонуються як структура для психологічної частини роботи.

В одному з небагатьох письмових звітів С. Гротовського - книжці «На шляхах до вбогого театру» (1965 р.), відображено інтеграцію фізичних, вокальних, розумових, емоціональних та енергетичних складових життя актора, котрі сприяють особистісному розумінню через саморозкриття до правдивості, як мети. На думку деяких вчених, ця праця є свого роду словником для навчання актора. Наприклад, термін «Шлях заперечення» («Via negativa») виражає необхідність видалення блокування, перед тим як актор зможе віднайти правдивість вираження та присутності. За словами С. Гротовського (1995, pp. 16-17) головна увага методики зосереджена на «дозріванні» актора через викорінення блоків.

Є. Гротовський не випадково відмовився від кодифікації або запису методики - своєрідної філософської школи, наближеної до духовних практик,- він вважав, що усталене в письмовій формі легко можуть неправильно трактувати, більше того, висловлював думку, що техніка, яку він наслідує, його власна методика, вміщує постулат про «глибоку зраду», бо якщо учень відчуває власну техніку, то віддаляється від інструктора, від його потреб, які той розуміє на своєму шляху, через свій власний процес, а відтак кожна інша методика є стерильною (Kumiega, 1985, p. 111). «Глибока зрада» — процес позитивний, оскільки завдяки віддаленню від техніки інструктора, актор стає сам собі вчителем. Багато акторів та режисерів, які тренувалися за методикою Є. Гротовського і продовжують викладати й понині, передають його методику в найкращий спосіб використовуючи те, що дізналися безпосередньо від iї засновника, задля створення власного підходу до роботи. Дана методика лишається актуальною, оскільки їі розвиток та еволюціонування, розпочаті 3 моменту створення, тривають і нині.

На сучасному етапі маємо декілька відомих новаційних методик, котрі базуються на психофізичних тренінгах С. Гротовського; їх викладають у багатьох провідних світових мистецьких навчальних закладах і не лише в європейських країнах, а й у США (наприклад, Школі мистецтв Тіш Нью-Йоркського університету (NYS's Tisch School of the Arts) — центрі навчання в галузі виконавського та медіа-мистецтва; Йєльській школі драми (Yale School of Drama) — факультету Йєльського університету (Нью-Хейвен, Конектікут) та ін.).

Неабияке зацікавлення викликає педагогічний практикум «Акробатика серця», розроблений режисером С. Вангом на основі фізичних вправ тренінгу С. Гротовського, який спрямований на розкриття шляху до внутрішньої творчості актора; фізичний спецкурс підготовки актора за методикою Е. Фей, в якому глибинне вивчення фізичних форм кішки (пластика тіла) пов'язується з практикою усвідомлення та емоційною роботою - в контексті застосування у розробці образу в будь-якій естетиці постановки; методики В. Хейвал, Р. вон Велденбург та ін.

Слід зазначити, що більшість методик, присвячених фізичним та психофізичним навичкам акторів, хоча й використовують різноманітну лексику та вправи, мають аналогічну суть, адже спрямовані насамперед на формування глибинного розуміння поняття «Я» та розширення діапазону фізичних виражальних засобів актора. Аналіз провідних методик дає змогу вирізнити термінологічні поняття, котрі поєднують головні концепції кожної з них: «nсихофізичне», «час» та «навколишнє середовищзе» (простір), «самопізнання», «структура» (або «склад»), «фокусування», «усвідомлення» (або «осмислення»), «присутність», «імпульс» та «зображення», «фізичне прослуховування».

Кожна методика потребує участі всього актора («ncuхофізичне») — голосу, тіла та розуму, важливість залучення яких є рівнозначно необхідною, оскільки розум впливає на тіло, а тіло, в свою чергу, впливає на розум. Вони є взаємозамінними агентами та виконавцями дій і реакцій.

Обов'язковою умовою тренінгів є психофізичне дослідження навколишнього середовища (простору) та часу через конкретну лексику та вправи. У ранніх тренінгах Є. Гротовського актор працює над додатковими сферами фокусування поза собою, 
проте практично завжди з точки зору тіла. Відтак у точках обзору фокусування відбувається довкола точки бачення часу та простору. У різноманітних ситуаціях сприйняття актором часу та навколишнього середовища впливає на його реакцію, отже методики визнають діапазон можливих способів взаємодії з власними маркованими категоріями часу та простору. Зазначимо, що лексика та/або вправи тренінгів (методик) спрямовані на психофізичне осмислення, тобто залучення тіла і розуму в процес дослідження самопізнання задля розвитку цього осмислення та поповнення фізичної лексики актора. Таким чином, каталогізуючи особистісні реакції як на власні зміни, так і на ті, що відбуваються поза ним, актор перебуває в динамічному взаємозв'язку 3 його реакціями та виборами.

«Самопізнання» в акторському навчанні розвивається при виборі персонажа, створенні динаміки та текстури, що їх можна проаналізувати 3 точки зору часу та простору. Методика Є. Гротовського потребує такого ж самовиявлення, проте у тренінгу головна увага приділяється внутрішній реакції, а не дослідженню зовнішніх факторів. Усі методики сприяють самопізнанню через експеримент та дослідження, а не техніку навчання чи дотримання запропонованого стилю руху, бо кожна 3 них потребує від актора віднайдення природної реакції на роботу та прогрес з цієї інформованої точки зору.

Кожен із методів пропонує власну «структуру» (або «склад») для акторів. Так, наприклад, «Groostowski's Corporeals \& Plastiques» забезпечує структуру, яка відображає важливу інформацію про фізичні стимули актора - рухи відкриття грудної клітини та відведення плечей назад можуть спровокувати відчуття відкритості, а отже і вразливості, проте підняття голови та подовження шиї-відчуття себе сильним. Отож у межах фізичних досліджень, актор реагує на внутрішні реакції та зовнішні рухи. Відповідно до методики, актори гармонійно взаємодіють один із одним завдяки дії в групі, яка має загальну мету. Навколишнє середовище відіграє роль у рухах, проте форма настільки жорстка, що отримана інформація допомагає акторові зрозуміти, яким чином налаштовується його фізична форма i реагує у дещо специфічному контексті. У цьому разі важливо не думати, а діяти стосовно точок зору, проте інколи акторам потрібна певна практика, щоб заспокоїти мислення та навчитися відрізняти корисні думки від деструктивних.

Практика «фокусування» в методиці Є. Гротовського функціонує як візуальна техніка для підвищення обізнаності; спонукає застосовувати м'який погляд, зосереджуючись на потоці рухів групи та особистому русі одночасно. Слід зазначити, що фокусування тіла та розуму проявляється різноманітними способами та відображає цінну для актора інформацію, розширює діапазон почуттів за межами ïx повсякденного використання, що призводить до підвищення обізнаності.

«Усвідомлення» (або «осмислення») актора про звички та інстинкти мають важливе значення в контексті осмислення їх позитивного та негативного впливу. Зазначимо, що у більшості випадків твердження Є. Гротовського про те, що «тіло зникає і глядач бачить лише ряд видимих імпульсів» (Grotowski, 1995, p. 16) інтерпретується як необхідність втрати набутих актором звичок, проте на сучасному етапі інструктори фокусуються на уважному дослідженні звичок та використанні поняття «вже» — стану, в якому актор перебуває перед певним етапом роботи. Наприклад, стан страху, який, з одного боку, може бути даремним для актора, якому треба зобразити хоробрість на сцені, а з іншого,- визнаючи свій первісний стан страху, актор вчиться використовувати енергію, властиву цьому стану та спрямовувати ії в продуктивну фізичну дію задля підтримки стану свого персонажа. Викорінювати цей страх потрібно лише тоді, коли він проявляється в повторенні нав'язливих думок, котрі блокують або пригнічують реакції актора.

Зауважмо, що усвідомлення стосується не лише звичок та інстинктів, а й визнання актором та акцентування уваги на психофізичному стані та стосунках із навколишнім середовищем і часом для особистісного зростання. Самовиявлення неможливе без осмислення та каталогізації безлічі подробиць, що їх актор усвідомлює під час роботи.

Другою необхідною умовою щирої, спонтанної реації, окрім осмислення, є «присутність», за визначенням Є. Гротовського,- не лише «обов'язкова присутність на місці роботи, а й фізична готовність до ії створення» (1995, p. 261). Осмислення безпосередньо пов'язане з присутністю - воно ніби породжує іiі, оскільки актор стає зацікавленим у ситуації, а не намагається зробити ії такою. Великою мірою присутність — це здатність «спустошити» себе, щоб стовідсотково, фізично та думками бути у стані «тут і зараз». На думку Д. Чайкіна, відомого американського театрального режисера і актора, який стверджував, що «кінцева цінність театру — це протистояння всіх живих тіл в кімнаті зі смертністю, яку вони поділяють: вісцеральна конфронтація з реальністю, що людина живе зараз», присутність стає своєрідним зіткненням виконавців та загальних реалій глядачів та емоціональних 
реакцій, котрі поєднують ці дві групи людей — їх спільна реальність включає світ поза простором постановки (Pasolli, 1970, p. 83). Акторська майстерність передбачає не лише емоційне поєднання 3 навколишнім середовищем та вміння передавати відносини за допомогою свого тіла, а й здатність створити міцний зв'язок для глядача через глибинну увагу до навколишнього середовища.

Є. Гротовський визначає «імпульс» як потенціал для дії, який може виходити з тіла або навколишнього середовища поза тілом і поєднує фізичне та психологічне через зображення або асоціацію. Відповідна реакція на появу ментальних образів може відбуватися шляхом фізичного наслідування зображенням (наприклад, повторення колових рухів тулуба в деяких вправах за методикою Гротовського), блокування образів та потурання емоційному бажанню. Уявні обставини сповіщають про різноманітні стадії, коли актор додає внутрішні відповіді та реакції через втілення проявів відчутих імпульсів.

Метою психофізичного тренінгу Є. Гротовського $є$ сприяння розробки актором власного діапазону фізичної виразності («фізичне прослуховування»).

На нашу думку, жодна з наявних новаційних методик психофізичного тренінгу за $€$. Гротовським не може бути визнана бездоганною для усіх акторів без винятку, проте кожна з них пропонує нескінченні можливості для саморозвитку та самовдосконалення шляхом навчання.

Наразі людські рухи лишаються недооціненими як основний компонент театрального мистецтва більшість традиційних театральних курсів і тренінгів зосереджують увагу на текстовому аналізі, вокальній техніці та емоційній складовій характеру персонажа, а також опрацюванні специфічних засобів мовної виразності. Проте введення аналізу рухів в усі типи театральних класів, а також визначення чіткої мови аналізу рухів сприятимуть підвищенню акторської майстерності, новаційним підходам у роботі над створенням художнього образу.

Висновки. Методика Є. Гротовського сприяє віднайденню актором глибокого розуміння себе та своєї професії за допомогою психофізичного дослідження того, як вийти за межі звичок та блоків. На сучасному етапі театральними режисерами та акторами - інструкторами методик за психофізичним тренінгом Є. Гротовського, досліджено розумові та фізичні перешкоди, які найчастіше проявляються в акторів на сцені, а також розглянуто роль уяви в навчанні акторів на основі рухів. Специфіка новаційних методик навчання акторів полягає не в копіюванні концепцій та вправ тре- нінгу Є. Гротовського, а в своєрідній адаптації та розвитку набутих навичок у поєднанні з власними підходами. Проаналізовані нами методики засвідчують здатність актора розвинути власні не лише фізичні, а й духовні здібності, проте не шляхом оволодіння професіональних навичок, а шляхом досягнення абсолютної цілісності фізіологічних та інтелектуальних здібностей, а відтак актуалізують питання формування термінологічної бази та системи критеріїв новітніх підходів до сценічної акторської майстерності.

\section{Джерела та література}

1. Grotowski J. Towards a Poor Theatre. London, UK: Methuen Drama Book, 1995. 264 p.

2. Komorowska M. In Jerzy Grotowski's Theatre. Voices from Within: Grotowski's Polish Collaborators / ed. by Paul Allain and Grzegorz Ziółkowski. London and Wrocław: PTP, 2015, pp. 46-60. DOI 10.15229/ptpcol.2015. voices.05.

3. Kumiega J. The Theatre of Grotowski. London, UK and New York, NY: Methuen, 1985. 290 p.

4. Osinski Z. Grotowski i jego Laboratorium. Warszawa, 1980. $409 \mathrm{p}$.

5. Pasolli R. A Book on the Open Theatre. Ann Arbor, Michigan: The University of Michigan Press, 1970. 132 p.

6. Richards T. At Work with Grotowski on Physical Actions. London UK \& New York, NY: Routledge, 1995. 135 p.

7. Slowiak J., Jairo C. Jerzy Grotowski. London, UK and New York, NY: Routledge, 2007. 208 p.

8. Smith W. The Commedia Dell'arte: A Study in Italian Popular Comedy. Columbia University Press, 1912. 330 p.

9. Toporkov V. O. Stanislavski in Rehearsal. Trans. Christine Edwards. London, UK \& New York, NY: Routledge, 1998. $224 \mathrm{p}$.

10. Zimmer H. De weg tot het Zelf. Leer en leven van de Indische heilige, Sri Ramana Maharshi uit Tiruvannamalai, Bijzonderheden: Uitgeverij De Driehoek, 1948. 248 p.

\section{References:}

1. Grotowski, J. (1995). Towards a Poor Theatre. London, UK: Methuen Drama Book, 264

2. Komorowska, M. (2015). In Jerzy Grotowski's Theatre. Voices from Within: Grotowski's Polish Collaborators. London and Wrocław: PTP. DOI 10.15229/ptpcol.2015. voices.05.

3. Kumiega, J. (1985). The Theatre of Grotowski. London, UK and New York, NY: Methuen, 290.

4. Osinski, Z. (1980). Grotowski i jego Laboratorium. Warszawa, 409.

5. Pasolli, R. (1970). A Book on the Open Theatre. Ann Arbor, Michigan, The University of Michigan Press, 132.

6. Richards, T. (1995). At Work with Grotowski on Physical Actions. London, UK \& New York, NY: Routledge, 135.

7. Slowiak, J., Jairo, C. Jerzy Grotowski. London, UK and New York, NY: Routledge, 208.

8. Smith, W. (1912). The Commedia Dell'arte: A Study in Italian Popular Comedy. Columbia University Press, 330.

9. Toporkov, V. (1998). O. Stanislavski in Rehearsal. Trans. Christine Edwards. London, UK \& New York, NY: Routledge, 224.

10. Zimmer, H. (1948). De weg tot het Zelf. Leer en leven van de Indische heilige, Sri Ramana Maharshi uit Tiruvannamalai, Bijzonderheden: Uitgeverij De Driehoek, 248. 